\title{
THE EFFECTS OF MEDIA AND THEIR LOGIC ON LEGITIMACY SOURCES WITHIN LOCAL GOVERNANCE NETWORKS. A three case comparative study ${ }^{1}$
}

\section{Iris Korthagen \\ Ingmar van Meerkerk}

\begin{abstract}
Although theoretical and empirical work on the democratic legitimacy of governance networks is growing, little attention has been paid to the impact of mediatisation on democracies. Media have their own logic of news-making led by the media's rules, aims, production routines and constraints, which affect political decision-making processes. In this article we specifically study how media and their logic affect three democratic legitimacy sources of political decision making within governance networks: voice, due deliberation and accountability. We conducted a comparative case study of three local governance networks using a mixed method design, combining extensive qualitative case studies, interviews and a quantitative content analysis of media reports. In all three cases, media logic increased voice possibilities for citizen groups. Furthermore, it broadened the deliberation process, although this did not improve the quality of this process per se, because of the media focus on drama and negativity. Thirdly, media logic often pushed political authorities into a reactive communication style as they had to fight against negative images in the media. Proactive communication about projects, such as PR strategies and branding, is difficult in such a media landscape.
\end{abstract}

Key words: Media logic; mediatisation; democratic legitimacy; governance networks; citizen groups; water management

\footnotetext{
${ }^{1}$ The article has been published in Local Government Studies (2014), Volume 40, Issue 5, p.705-728, and can be found at: http://www.tandfonline.com/doi/abs/10.1080/03003930.2013.859139\#.VDf1c2d_veA
} 


\section{Mediatised Legitimacy within Local Governance Networks}

In contemporary democracies, political authorities often experience tremendous difficulty in legitimating their position and actions, especially in response to complex societal issues that cross different institutional boundaries (e.g. Beck et al. 2003, Hajer 2003, Peters 2010). Media play an important role in legitimising processes (Habermas 2006, Hajer 2009). In this article, we are interested in the influence of the media, and particularly media logic, on the democratic legitimacy of political decision making in governance networks. Although the democratic legitimacy of governance networks is a highly debated issue in the literature (e.g. Pierre 2000, Papadopoulos 2003, Sørensen and Torfing 2005), little attention is paid to the impact of the media and media logic in this respect (e.g. Hajer 2009). Important sources of democratic legitimacy, such as voice, due deliberation and accountability, are influenced by the media. The media could be used as a vehicle for stakeholders to put their issues on the political agenda. They could provide a platform for debate and also act as a forum for political authorities to brand their policies and to create legitimacy for their actions.

However, the media are not neutral information transmitters, but, like all institutions, shape and select information in certain ways (Altheide and Snow 1979, Mazzoleni and Schulz 1999, Cook 2005, Parkinson 2006). The process of news-making led by the media's rules, aims, production routines and constraints is known as media logic (Altheide and Snow 1979, Brants and van Praag 2006, Hjarvard 2008, Strömbäck and Esser 2009). News-making depends to a great extent on the news values that journalists ascribe to events or viewpoints, but also on organisational pressures on journalists such as deadlines and economic goals (Shoemaker and Reese 1996). Research by Patterson (2000) and Bennett (2009) has identified general trends in this media logic: news is increasingly negative, particularly towards authorities, as well as dramatised and personalised.

An important question then is how these characteristics of media logic affect sources of democratic legitimacy within governance networks, which we examine in this article. In the literature on mediatisation, it is argued that, within present-day democracies, media and their logic are very influential, even to the extent that media 
logic overrules other institutional logics, such as political logic (Mazzoleni and Schulz 1999, Cook 2005, Strömbäck and Esser 2009).

We conducted a comparative case study of three local water management projects, using a mixed method design. Although we are aware that a variety of actors are involved in governance networks, we concentrate on two important groups of actors relevant to the democratic legitimacy of political decision making: political authorities and citizens (organised in citizen groups). To measure the presence of media logic and media attention on both citizen groups and political authorities, we conducted a quantitative content analysis on media reports about the projects $(\mathrm{N}=290)$. Case study analyses, and specifically interviews with key representatives of both groups, were used to further examine the way in which citizen groups and political authorities interacted with the media and how this affected legitimacy sources.

In the first part of the article, we elaborate how media logic could theoretically influence different sources of democratic legitimacy in governance networks. In the second part, we discuss our mixed method design. This is followed by an analysis of the results of our study. Lastly, we discuss our findings in the concluding section.

\section{Democratic Legitimacy as a Communicative Process between Political Authorities and Citizens}

In this study we focus on governance networks around complex water projects. Complex water projects could be typified as boundary-crossing public issues, as they cross different geographical, societal, administrative and institutional borders (Edelenbos and Teisman 2011; van Meerkerk et al. 2013). The network around such projects consists of a variety of interdependent governmental, private, and societal actors (including citizen groups), who interact with each other to influence the policy and decision-making process by means of negotiation, persuasion, and collaboration (Van Buuren et al. 2010; Edelenbos et al. 2013).

The democratic legitimacy of political decisions in such governance networks is not straightforward as there are no clear constitutional rules and norms that determine what constitutes a legitimate decision. As Hajer (2009, p. 30) rightly points out: 'the primacy of the politics presupposes that the council of elected representatives confers 
legitimacy on the decisions it takes. Yet when policy problems do not respect the territorial scales, this system breaks down.' This means that, in the words of Warren (2009, p. 7), 'the legitimacy generated by electoral democracy does not carry over to [these] issue-segmented constituencies.'

Many authors therefore stress the importance of communicative relationships between political authorities and affected stakeholders in the construction of legitimacy for political decisions in governance networks (e.g. Bang 2003, Dryzek 2010). Traditional policymaking is characterised by a domination of expert-based knowledge and rather unilateral modes of communication between experts and decision makers (Crozier 2008, Wagenaar 2007). Information flows in governance networks are rather multilateral, and communicative capacity is more egalitarian. Furthermore, 'messages undergo transformations as receivers interpret and process information in creative and self-referential ways that can easily escape the original intentions of the sender' (Crozier 2008, p. 9). Media, as an important communication channel, also select and transform information.

Generating legitimacy is for an important part dependent on managing information flows, as relevant information loops concerning policy and decision making are more integrative and dynamic. Different stakeholders part of the governance network contribute to the generation and spreading of information in the policy and decisionmaking process, not seldom using media.

By legitimacy we mean a generalised preparedness to accept, within a certain margin, a decision or policy by those to whom it is supposed to apply (see Luhmann 1975). As decisions and policymaking around complex governance issues often take a considerable amount of time (e.g. Teisman 2000), in which preferences and perceptions of actors can change, we could therefore also speak of a process of acceptance (cf. Dryzek 2010). This is also emphasised by deliberative models of democracy, which locate the source of legitimacy in the process of deliberation between actors (Manin 1987). In this process of acceptance, different sources of legitimacy are important. 


\section{Different sources of legitimacy in governance networks}

Various models of democracy stress varying sources of democratic legitimacy. We focus on three different sources of democratic legitimacy that are especially relevant for analysing decision-making processes in governance networks (see Klijn 2011). These three sources derive mainly from the deliberative model of democracy. This model goes relatively well with the nature of governance networks, as compared to more traditional models of democracy (Sørensen 2002, Dryzek 2010, van Meerkerk et al. 2014). ${ }^{\mathrm{i}}$

As a first source of democratic legitimacy in governance networks, voice is an important consideration. Voice is about the way in which affected stakeholders can provide input in the decision-making process (Manin 1987, Dryzek 2007). To what extent are citizens enabled to express their wishes and interests in political decision making and how easy is it to get issues on to the political agenda (Bekkers and Edwards 2007)? Secondly, democratic legitimacy in governance networks is dependent on the quality of the deliberation process: due deliberation. To what extent are different perspectives included in the decision-making process? In this sense, legitimacy is derived from the extent a decision receives reflective assent through participation in authentic deliberation by those subjected to the decision in question (Cohen 1989). Mutual exchange of information, perceptions and preferences could induce a learning process by which wellinformed and reasoned decision making could take place. This is grounded on the assumption that individuals' preferences are not fixed, but can change in debate and political dialogue (Held 2006). The transparency of the decision-making process and open information access are also often mentioned parameters of due deliberation (Dryzek 2000). Accountability of decision makers to the public is a third source of democratic legitimacy. In governance networks, accountability is often diffuse and spread among different actors and governmental layers (Van Kersbergen and Van Waarden 2004, Hajer 2009). However, particular officeholders often function as the public face around decisions or a specific policy (Eshuis and Klijn 2012). Providing information and explaining certain decisions in the media is important for politically responsible actors to generate legitimacy and to convince their electorate that their actions are right and necessary. 


\section{Mediatised legitimacy}

\section{Role of media in democracies}

Graber (2003) summarises four different functions of news media within democracies (p. 143):

- Providing a forum for discussion of diverse, often conflicting ideas;

- Giving voice to public opinion;

- Collecting information about political events, serving as citizens' eyes and ears to survey the political scene and the performance of politicians;

- Acting as a public watchdog that 'barks loudly' when it encounters misbehaviour (e.g. corruption, abuse of power) in the halls of government.

Although these are potential functions of news media, rather than an accurate description of their routine performance (Graber 2003, 2004), these functions are strongly connected to the legitimacy sources discussed above. The media can open up the political and policy agenda, giving voice to citizen groups. Furthermore, as they provide a forum for discussion, they impact on the quality of the deliberation process. Thirdly, as they inform citizens about the performance of politicians, they affect the accountability relationship of political authorities towards citizens. The media facilitate or mediate these legitimacy sources, at least to some extent. In this matter, it is important to consider how the media operate, as they are not neutral information transmitters, but have their own logic (Altheide and Snow 1979, Mazzoleni and Schulz 1999, Parkinson 2006). In the next section, we describe how this media logic potentially affects the role of the media regarding the three sources of legitimacy.

\section{Mediatisation}

As discussed in the introduction, media logic refers to 'the process by which media present and transmit information' (Altheide and Snow 1979, p. 10), led by the media's rules, aims, production routines and constraints. Complex policy processes are often tremendously reshaped to fit the journalistic norms of newsworthiness and media formats (Davis 2007, Bennett 2009). Bennett (2009) describes several trends in news reporting 
that, in his opinion, simplify complex governmental issues. He sees information biases of personalisation (a focus on human interest), dramatisation (an emphasis on crisis and conflict) and an authority-disorder bias (a claim that authorities are not able to establish or restore order in society) (Bennett 2009). In addition, Patterson (2000) observes a bias towards negativity in the news. These trends in the news can also be found in other studies on media content (see Brants and Neijens 1998, Semetko and Valkenburg 2000, Brants and van Praag 2006, Kleinnijenhuis et al. 2006, Strömbäck and Sheheta 2007).

Many scholars argue that societies and societal institutions are submitted to, or become dependent on, the media and their logic to an increasing degree; they are increasingly mediatised (Hjarvard 2008, Mazzoleni and Schulz 1999, Reunanen et al. 2010, Strömbäck and Esser 2009). In the context of politics, Mazzoleni and Schulz (1999, p. 250) argue: 'mediatized politics is politics that has lost its autonomy, has become dependent in its central functions on mass media, and is continuously shaped by interactions with mass media.' Meyer (2002) even speaks of a 'colonisation' of politics by media logic. As political actors adapt their communication strategies and even tailor their policy decisions to fit the media's needs of timing, staging and framing, media logic dominates over political logic. Others expect that some institutions, policy stages and activities in the political process will be more mediatised than others, depending on how compatible they are with media logic (see Esser and Matthes 2013).

In this study, we empirically examine the extent to which and how legitimacy sources are mediatised in different stages of the policy process.

\section{Mediatised voice}

Voice refers to the opportunities for citizens to participate and influence decisions. To what extent can they influence the decision-making agenda and can they exercise voice during the governance process with the help of media attention?

Citizens often organise themselves in citizen groups. Although these groups are often to some extent involved in processes of network governance, they have less power resources than other actors in the decision-making process. Citizen groups can increase their influence by gaining media attention (Kunelius and Reunanen 2011, Spörer-Wagner and Marcinkowski 2010). They then strive to shape the news in order to set their issue 
and their frame on the agenda of decision makers; this is also known as agenda setting (Baumgartner and Jones 2009, Cobb and Elder 1983, Cook et al. 1983, McCombs 2004) and framing power (Fischer 2003, Terkildsen et al. 1998). As Entman (2007) argues, decision makers use the news as a surrogate for public opinion. In this respect, news coverage of a citizen group's statements may change the targets and efforts of decision makers in the decision-making processes. News reports influence the context in which officials bargain and decide (Cook 2005).

Since media logic influences the selection and framing of societal actors' messages (Mazzoleni and Schulz 1999), we argue that it plays an intermediating part in the source of voice. Success in shaping the news is often more related to journalistic norms than to actual pressure group strength as Terkildsen et al. (1998) note. They mention the following criteria as influencing this success: spokespersons' accessibility, rules of issue simplicity, drama and event-oriented coverage. Journalists need spokespersons to fill news holes, to meet deadlines and to provide drama (Terkildsen et al. 1998). In other words, citizen groups are submitted to, and become to a certain extent dependent on, media logic if they want to influence the decision makers' agenda via media attention. Therefore, we could presume that the degree to which they are able to adapt to media logic affects their success.

\section{Due deliberation and mediatisation}

Habermas (2006) argues that the media play an important role in deliberative processes by facilitating flows of political communication throughout the political system in a public sphere. The media collect, select, assemble and interpret relevant issues and require information from the flows of political communication. They ideally could, if only circumstances were favourable, generate considered public opinions (Habermas 2006).

However, these functions of the media in the deliberative process can become problematic if the media focus excessively on the negative, dramatic or emotional aspects of governance processes (Mazzoleni and Schulz 1999, Habermas 2006, Bennett 2009). Rohlinger (2007, p. 145), in addition, reproaches the media for presenting only the most extreme elements, thereby undermining the deliberative process. In this respect, 
information biases seem to problematise the function of the media as a public platform for diverse deliberations. Many authors suggest that the legitimacy of political authorities is under pressure in the media debate, merely because of critical reporting about them (Patterson 2000, Kleinnijenhuis et al. 2006, Bennett 2009, Hurrelmann et al. 2009).

At the same time, many political actors are assisted by public relations practitioners and spokespersons who bridge the differences between governmental or political logic and media logic (Davis 2002). They provide information subsidies to journalists to 'sell' policy plans; official sources are therefore not only authoritative but also efficient news sources (Davis 2002, Cook 2005, Louw 2007, Eshuis and Klijn 2012). In times of increasing time pressure on journalists, these information subsidies have quite an impact on news reporting (Davis 2002).

An unlovable press can therefore be seen as essential for the functioning of democracy. In particular, the often criticised characteristics of media logic - the preoccupation with events, with conflict and the cynicism of the media - may contribute to the subversion of established power (Schudson 2009). This could prevent interests of minority groups being easily pushed aside by powerful public and private stakeholders in the deliberative process.

\section{Mediatised accountability relations}

According to Hurrelmann et al. (2009, p. 487), the media serve as 'the primary interface $[\ldots]$ between citizens and the representatives of political systems; media debates on political issues juxtapose the self-legitimating claims of these elites and the legitimacy assessments of important stakeholders or professional observers.' When political actors and governmental institutions want to publicly legitimate their decisions, the media are a highly important resource. As discussed earlier, the degree to which political authorities are able to adapt to media logic influences whether they manage to present their policy decision as successes. Through information subsidies such as press releases, press conferences, pre-arranged interviews and press tours - which are nowadays fully integrated into the process of news production - they pro-actively communicate their policy decisions and suppress potentially damaging stories (Davis, 2002). Adaption to media logic may decrease the quality of information that voters can obtain from media 
reports on public affairs (Mazzoleni and Schulz 1999, Davis 2002, Hjarvard 2008, Bennett 2009). The authorities have thus professionalised their communication strategies, but Jacobs (2009) points out that the logic in news reporting can lead to coercive, reactive legitimation of decisions made. When the media increasingly focus on drama and conflict and hold authorities responsible for failures in governance processes, authorities have to react to these accusations and increase their efforts to legitimate their decisions.

\section{Mixed Methods}

To examine the influence of media logic on democratic legitimacy sources, we have developed a mixed method design, combining quantitative and qualitative methods to generate more knowledge on the phenomenon (Currall and Towler 2003).

\section{Data: three governance networks around complex water projects}

We studied three water management cases in the Netherlands: a bypass in IJsseldeltaZuid (near Kampen), a dike relocation in Lent (in Nijmegen) and a dike relocation in the area called the Noordwaard (near Werkendam). These cases are part of a national governmental programme, called Space for the River (Ruimte voor de rivier), which started officially in 2000. This programme strives for a collaborative, interactive governance approach aiming to increase the involvement of local citizens and investors in the planning process (website Ruimte voor de Rivier, van Buuren et al. 2010). As the national government leaves project development to the regional and local governments, executive local politicians often function as the face of these projects or the first political point of contact for citizens.

The complex water projects are about new ways to improve water safety (reducing flood risks) in combination with spatial quality. As these water safety measures make a big claim on space in and near cities, they are confronted, and often combined, with other planning activities and ambitions of local and regional governments, such as housing, the development of recreational areas and infrastructure.

We approached the projects as governance networks, following previous research on these same projects (see van Buuren et al. 2010, Klijn et al. 2010, Edelenbos et al. 
2013). These projects (a) involve many actors (public actors such as local government, water boards, province; private actors such as building companies; and societal groups, such as environmental organisations and inhabitants), (b) have a relatively stable character, i.e. they have been in existence for a long period and are characterised by regular interactions between the actors, and (c) are dominated by wicked problems, i.e. the solutions proposed for problems and challenges are contested because the different actors have divergent perceptions of the problems and solutions (Edelenbos et al. 2013).

In short, the water projects are developed and implemented in networks of interdependent actors, who employ dynamic interaction processes with one another and who lack clear relations of domination and subordination (although power inequalities exist). In all three cases, citizen groups are involved, using different strategies to influence the policy and decision-making process. The interactions between the actors are typified by a mix of negotiation, collaboration, persuasion and mutual adjustment. Besides direct interaction with one another, these actors could also use 'go-alone' strategies to strengthen their position (see Koppenjan and Klijn 2004).

The three cases have been studied extensively with regard to governance process (van Buuren et al. 2010) on the basis of Teisman's (2000) rounds model. ${ }^{\text {ii }}$ We use these decision-making rounds to organise our analysis.

\section{Quantitative content analysis}

The media reports about the three projects stem from newspapers and television. The selection of newspaper reports started at the Lexis Nexis Academic NL database. We used the name of each case ${ }^{\mathrm{iii}}$ as the search term, in the period from 1 January 2000 to 1 January 2011 as the Space for the River programme started in 2000. Besides these newspaper reports, we searched for television items on the website of the Dutch institute for television and radio (http://portal.beeldengeluid.nl/) and on regional broadcasters' websites. This resulted in a universe of 290 media reports.

In the quantitative content analysis, we used Patterson's (2000) coding scheme, items and coding instructions, which fit the information biases that Bennett (2009) describes (see also Korthagen 2013). We focused on:

- dramatisation (news report has a substantial level of conflict framing); 
- personalisation (news report has high or moderate human-interest framing)

- negativity (news report is clearly negative/more negative than positive);

- authority-disorder bias (news report implies a need for action and attributes this to a governmental institution).

Furthermore, we developed an item by which one key subject in the report was identified. The categories of this item were based on case study research (van Buuren et al. 2010). ${ }^{\text {iv }}$ Three teams of trained coders coded the news reports, with the help of an extensive coding instruction. We executed two reliability tests: intra-coder (0.94) and inter-coder (0.91). These scores indicate that the dataset can be seen as reliable.

\section{Interviews}

Besides the interviews used to elaborate the case descriptions and analysis on the basis of the rounds model (see Van Buuren et al. 2010), we additionally interviewed both the politically responsible aldermen and the spokesmen for the citizen groups. These aldermen are the public face of the water projects. We picked the citizen groups most often present in the media reports: Citizen group Zwartendijk in the IJsseldelta-Zuid case, Citizen group Federation of Lent in the Lent case and citizen group Bandijk in the Noordwaard case. ${ }^{\mathrm{V}}$ In relation to the sources of legitimacy, we asked the respondents about the involvement of the citizen group in the decision-making process, about the quality of the deliberation process and the outcomes. We additionally asked them about their contacts with journalists, whether they made their message more attractive for journalists and, if so, how they did this, and the effects of media attention. All the interviews were face-to-face and took about 100 minutes. $^{\text {vi }}$ The interviews were fully transcribed.

\section{Results}

We first report the findings of our quantitative content analysis. Afterwards, we connect these findings to our interviewees' responses, discussing the impact of media logic on the three sources of legitimacy in governance networks. 


\section{Media attention in the different rounds of decision making}

From the universe of 290 media reports, 20 reports come from national news media (6.9\%), and 270 reports stem from local media (93.1\%). In addition, 280 reports stem from daily papers $(96.5 \%)$ against 10 items from television programmes ${ }^{\mathrm{vii}}(3.5 \%)$.

Who gets on the news?

Table 1 shows the different groups of key subjects grouped in four categories. For the purposes of this study, the executive politician and citizen groups are particularly important. In all three cases, citizen groups are key subject in about a third of the media reports. In IJsseldelta-Zuid and Lent, executives are somewhat more often key subject than citizen groups. In Noordwaard by contrast, executive politicians are key subject in only one in seven media reports, whereas citizen groups feature in almost one in two.

Adding these two groups, we see that in all three cases in a majority of the media reports citizen groups or executive politicians are the key subject. They are thus very important in the media debate.

Table 1. Media coverage of actors: percentages of actors as key subject in a news report

\begin{tabular}{|c|c|c|c|}
\hline & $\begin{array}{r}\text { IJsseldelta- } \\
\text { Zuid (N=100) } \\
(\%)\end{array}$ & $\begin{array}{r}\text { Lent } \\
(\mathrm{N}=97) \\
(\%)\end{array}$ & $\begin{array}{r}\text { Noordwaard } \\
(\mathrm{N}=93) \\
(\%)\end{array}$ \\
\hline (Prime)Minister/The state & 11.0 & $\overline{14.4}$ & $\overline{5.4}$ \\
\hline Provincial governor/ The province & 13.0 & 4.1 & 2.2 \\
\hline Municipal governor /The municipality & 10.0 & 16.5 & 8.6 \\
\hline Executive politicians total & 34.0 & 35.0 & 16.2 \\
\hline Inhabitants (association) & 21.0 & 29.9 & 28.0 \\
\hline Farmers & 2.0 & 1.0 & 9.7 \\
\hline Environmental organisations & 1.0 & 1.0 & 8.6 \\
\hline Citizens (group) total & 24.0 & 31.9 & 46.3 \\
\hline Administrative officials & - & 3.1 & 8.6 \\
\hline Water board & 1.0 & 1.0 & 1.1 \\
\hline Project organisation & 16.0 & 2.1 & 6.5 \\
\hline Member of the Lower House & 2.0 & 12.4 & 3.2 \\
\hline Member of the Provincial Council & 1.0 & 1.0 & 2.2 \\
\hline Member of the Municipal Council & 9.0 & 4.1 & 5.4 \\
\hline Other governmental actors total & 29.0 & 23.7 & 27.0 \\
\hline Private investors & - & 2.1 & - \\
\hline Research institute & 4.0 & 4.1 & 3.2 \\
\hline Other & 9.0 & 3.1 & 7.5 \\
\hline Other societal actors total & 13.0 & 9.3 & 10.7 \\
\hline
\end{tabular}




\section{Media attention in the different rounds of decision making}

In all three cases, citizen groups were part of the governance network, interacting with the initiating governmental actors and other stakeholders to negotiate and deliberate project plans. However, the juncture at which the citizen groups became involved, the way in which participation was organised and the extent to which they choose for a goalone strategy varies. These aspects form an explanation for the uneven distribution of media attention among the different rounds of decision making in all three cases, shown in figure 1.

In the Noordwaard case, the citizen group was strongly involved from the beginning, when interactive planning sessions were organised with a variety of stakeholders to develop the project plan, creating much room for voice and deliberation. However, in the last round, when the planning process was finishing and the implementation process started, the communication and interaction between stakeholders sharply decreased. At that time, citizen group members became increasingly dissatisfied about the execution of the governmental plans and they publicly started some fierce discussions about the consequences of the plans for citizens and compensation.

In the Lent case, the citizen group was part of the advisory committee of the project organisation. However, because they were not satisfied with the proposed project plan and opportunities for meaningful deliberation, they were also developing their own alternative. The number of media reports peaked when the local council supported the citizen group's alternative. This led to a difficult position for the responsible alderman (the political executive), who was negotiating with the national government.

In the IJsseldelta case, the concerned citizen group became involved relatively late. Although interactive sessions were organised here, this citizen group became involved in the sessions when the project plans became more concrete. The peak in news reports is in 2007-2008 when this citizen group strongly protested against the proposed development of the bypass, particularly with regard to the housing plans (see Van Buuren et al. 2010). They were able to put their concerns on the agenda of the local council. Subsequently, housing in the Zwartendijk area was postponed by the local council. 
Figure 1. Media attention in the different rounds of decision making in IJsseldelta-Zuid, Lent and Noordwaard

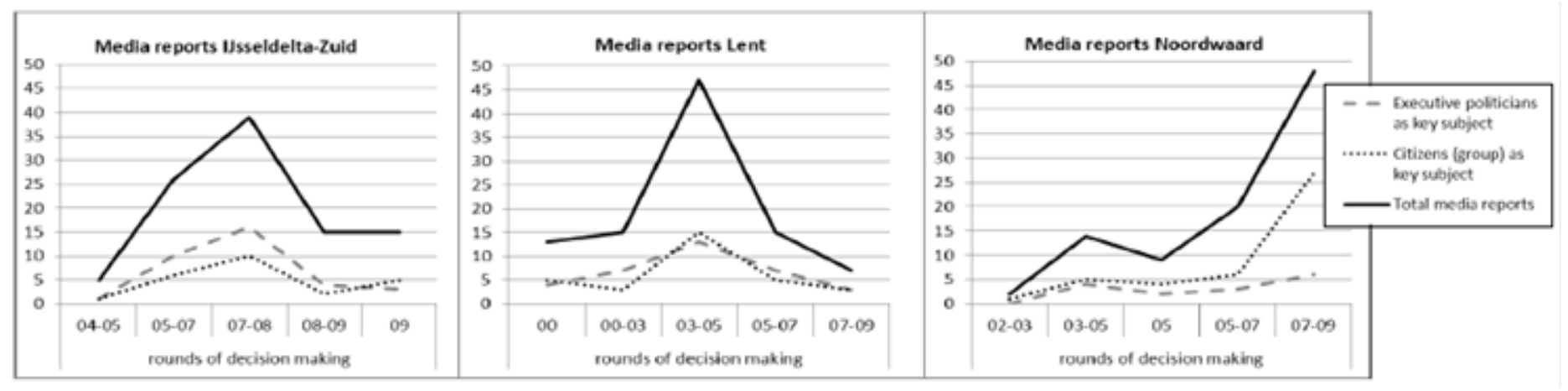

Note: $X$-axis $=$ time period. Each time period is a decision-making round. $Y$-axis $=$ number of media reports.

We can conclude that media attention was not constant during the three decisionmaking processes. Media attention increased at times of conflict between citizens and political authorities around the plans. This is when the legitimacy of important aspects of the policy plans were most contested by the citizen groups.

The presence of media logic in the news reports

Table 2 shows that all information biases appear in the news reporting on the water management projects. In most of the reports (more than $60 \%$ of all reports in each project) at least one of the information biases is present. The authority-disorder bias and the negativity bias are most often present, whereas the personalisation bias appears less often. The media logic presence seems to be the strongest in the Lent case (78\% versus 64 and 62\%). An explanation could be that in this case the citizen group proposed an extensive alternative plan, not only challenging and discussing the governmental plan, but really competing with it. ${ }^{\text {vii }}$ 
Table 2. Information biases in the news

\begin{tabular}{llcl}
\hline Biases & \multicolumn{3}{c}{ Media reports } \\
& IJsseldelta-Zuid (\%) & Lent (\%) & Noordwaard (\%) \\
\hline Dramatisation bias & 23.0 & 46.4 & 26.9 \\
Personalisation bias & 16.0 & 13.4 & 19.3 \\
Authority-disorder bias & 42.0 & 68.0 & 36.6 \\
Negativity bias & 45.0 & 54.6 & 40.8 \\
1 or more biases present in media report & 64.0 & 78.4 & 62.4 \\
\hline
\end{tabular}

Presence of media logic in reports on citizen groups versus reports on executive politicians

In Table 3, we report how the information biases relate to citizen groups as key subject and to executive politicians as key subject. Clear positive relations exist between information biases and citizen groups as key subject, especially with regard to dramatisation, personalisation and negativity. Stories about them contain more conflict, more human interest, more negativity towards the water project. The citizen groups do not seem to demand significantly more often than other groups of key actors that governmental authorities should take actions (authority-disorder bias).

In all three cases, reports about citizen groups score high on the personalisation bias. Reports on the citizen group in the IJsseldelta-Zuid case score highest in relation to dramatisation and the Lent citizen group in relation to negativity.

In contrast, we see in Table 3 no or only small negative relations between executive politicians and information biases. Significant negative correlations would show that, when executive politicians are key subject in a media report, the report has significantly fewer information biases. This would mean that reports are more positive, less dramatised, less personalised and have fewer demands for action by a governmental authority. This is probably what executive politicians strive for in media attention on their projects. Some politicians, especially concerning IJsseldelta-Zuid, seem to indeed succeed in telling their side of the story: reports are significantly less dramatised and more positive towards the project. However, in Lent and Noordwaard, these negative correlations are much smaller and not significant. Apparently, the executive politicians in 
these projects have more difficulty getting a more positive and less dramatised image of the project into the news.

Table 3. Relations between the information biases and the citizen groups/executive politicians

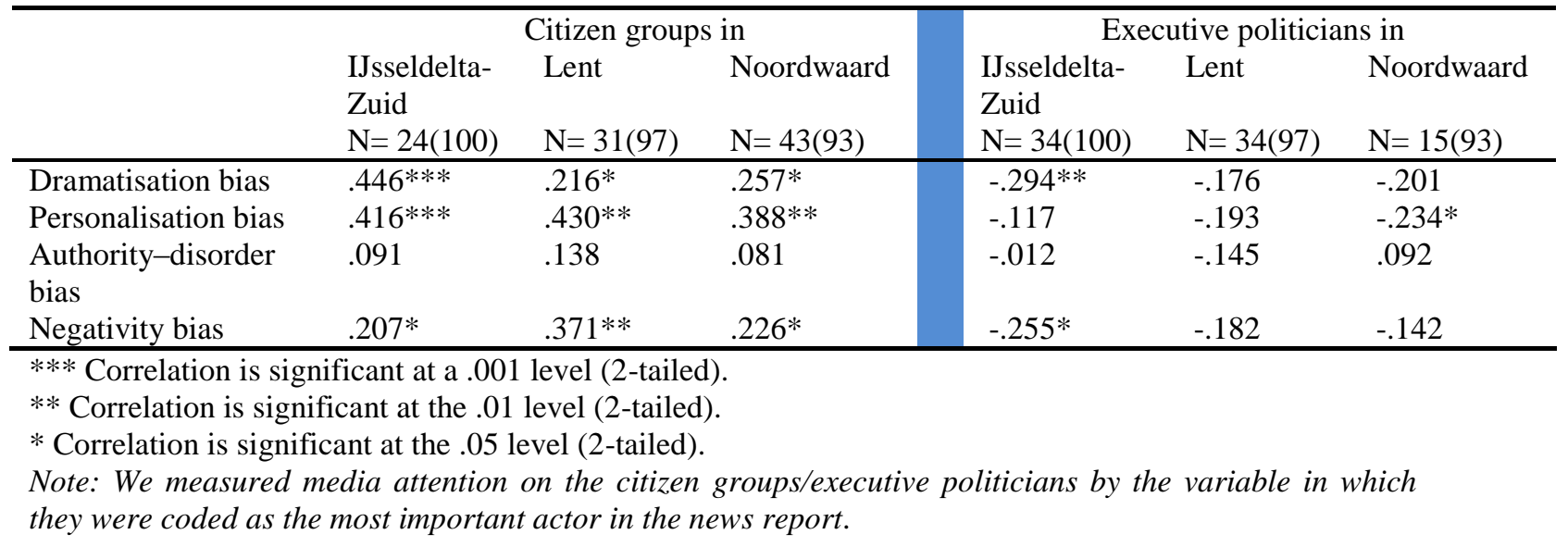

\section{Mediatised legitimacy}

In summary, the quantitative analysis of the media reports reveals that the media attention is quite erratic. Media attention increases in the rounds in which the legitimacy concerning the policy plans from the citizen groups' perspective is under most pressure. Furthermore, the findings show that executive politicians do receive media attention, but this attention does not always show a more positive side of the water projects. Media logic seems to make it harder for executive politicians to publicly legitimate their decisions and obtain broad social support for the water project via media reports, especially because citizen groups attract a lot of media attention as well; but this attention reflects many information biases. At several junctures, the citizen groups criticised the legitimacy of the policy plans and fought for their interests, deploying different strategies, such as arranging protest actions, designing alternative measures and/or participating in discussion forums. Media attention thereby potentially increased their power position. They seem to use the media and media logic quite well.

We conducted interviews with both citizen groups and executive politicians to further examine how they make use of the media in their political communication and how media logic consequently affects the three democratic legitimacy sources. 
Voice: media attention to influence the decision-making process

In all three cases, we observed citizen groups succeeding in attracting much media attention; in about a quarter to half of the media reports they were the key subjects in media reports (Table 1). The media reports were crucial in making them and their viewpoints known to the wider public and to the authorities. This strategy can get a much faster reply from the formal decision-making authorities, as the spokesman for the Noordwaard citizen group argues: 'I was amazed by how soon the Minister of State reacted to such a report in the newspaper.'

This media attention can contribute to changing decisions within the process. Although in the three cases the water storage plans and the other activities were not that much altered, some smaller decisions were made in favour of the citizen groups. In the IJsseldelta-Zuid case, the municipal council changed its decision about housing in the area in response to the actions of the citizen group and the consequent extensive media attention. In the Lent case, the citizens' alternative plan has been incorporated in the Environmental Impact Assessment (EIA), funded by the national government. Furthermore, the citizens pleaded for measures against seepage water. The publicity around these problems bolstered their viewpoint, as the alderman noted. Consequently, the municipality invested more money in instruments to prevent the area from seepage water and to monitor this. Regarding Noordwaard, the alderman noted that he created fewer recreational facilities to make concessions to the citizens, publicising his stance through the press.

How did these citizens obtain media attention for their story? As stated in the previous section, media attention on the citizen groups related strongly to the information biases of dramatisation, personalisation and negativity. Therefore, citizen groups' representatives used protest actions to attract journalists. 'You need something visual, something which they [the journalists] can see and you must provide some drama,' as the spokesman for the IJsseldelta-Zuid citizen group argued. One of their actions entailed driving a car with a homemade 'dike' on it through the city, with water leaking out of this dike. Children could stick their finger in the little holes in the dike; that led to speaking 
pictures in the local press. In the Lent case, the citizen group marked the route of the new dike with black flags. These kinds of actions play to media logic.

Besides these protest actions, citizen groups provided journalists with information about their viewpoints directly by emails, telephone calls or even a press conference. Letters written to governmental institutions were often also sent to the media. Furthermore, we found that they often showed awareness of journalistic needs. As the Lent citizen group representative noted: 'Some journalists were interested in the emotions of citizens who had to leave because of the relocation of the dike. I assessed what kind of story they wanted. Did they want a really emotional story? then I sent them to inhabitant $A$, did they want a more sober story? I sent them to inhabitant B.'

The citizens also found that less dramatic or negative stories were less attractive to the media. The Noordwaard citizen group representative stated that the press did not report on their collaborative experience with the political authorities in the first rounds of the decision-making process. Although this collaboration did not pass off easily, the citizen group was committed to collaborate. "The concerned journalist judged "this is not controversial enough, we won't come to report on your story".'

Overall, the citizen groups' representatives were satisfied with the media reporting on their case. Media logic seems to help citizens, especially when they explicitly protest against the measures proposed by the political authorities. The easy accessibility of the spokesmen and their feeling for media logic, communicating simple and dramatised messages certainly seemed to help in this matter. But what does this mean for the quality of the debate?

Due deliberation: media attention broadens the scope of the deliberative process In all cases, we observed a widening of the scope of the deliberative process consequent to the activities of the citizen groups and the attention they received from the media. By following the media, the aldermen received more information on citizens' viewpoints. By keeping in contact with the local journalist, the aldermen received more information about citizens' concerns. 'Just by keeping in touch with the local journalist, I got much information about the concerns of citizens in the area. You receive signals. They [the citizens] don't tell me everything, but they do tell [the local journalist] this,' as the 
Nijmegen alderman stated. In the IJsseldelta-Zuid case, the alderman noted on this matter: 'I don't experience this [the media attention on the citizen group] all in a negative manner. It has created more attention for certain aspects, such as the safety level, and provided more accurate information and transparency.' The Noordwaard alderman argued: 'The media performed quite well for the inhabitants, enabling them to express their criticism, as well as for us, making the signals stronger, so that we addressed those criticisms in our conversations with the ministry, on behalf of the inhabitants.' By providing more information on the citizens' concerns, the media reporting has thus broadened the scope of the deliberation process in the three cases.

However, media logic also caused a certain shift in focus, namely, a focus on negativity, drama, disorder and some human interest. As we saw in the quantitative content analysis, a majority of the media reports show at least one of the information biases. In this matter, the alderman responsible for IJsseldelta-Zuid argued that the media debate 'alluded to emotion, not to facts or the content of the plan.' Moreover, the media often seemed to side with the opposing citizen groups. 'Generally, the media mainly choose the critical side,' the Noordwaard alderman noted. The alderman in the Lent case aptly remarked: 'the citizen group receives rather much attention and they realise rather much participation space, although the governmental experts are convinced that the other plan is surely much better.' The alderman in the IJsseldelta-Zuid case questioned the extent to which the viewpoints in the media really represented the viewpoints included in the decision-making process: 'people who said that they were not involved in the process received maximum attention, whereas people who said they were involved, received minimum media attention.'

The quality of the deliberation process is thus to some extent increased by more information. However, at the same time, the quality might be decreased, since we can question the diversity of the perspectives covered in the media reporting. Media logic seems to restrict this diversity. 
Accountability: more reactive position than proactive communication due to dramatisation

The authorities needed media attention to obtain social support for the water project plans. When the national governmental decision about Space for the River had to be made, the ministry also used the press. The Lent citizen group representative argued: 'By short movies with an image of chairs in water, and images of floods in the future in the Netherlands, they argued that the Netherlands should take measures. They prepared us for the fact that much money is going to be spent on water management.'

However, it is not that easy to explain decisions in the media. As the correlations in Table 3 show, executive politicians cannot always 'escape' the presence of information biases in the media representation of their stories. Executive politicians' stories may be presented in a more negative and dramatised way than they want. In the Lent case, this was indeed so. The local authorities presented the project plans enthusiastically by showing how the area would look after the dike shift. The alderman stated: 'we wanted to communicate that this water project is also an opportunity for the area. But this came back as a boomerang. (...) The press thought it was pitiful for the inhabitants.' The media focused on the 50 dwellings that had to be removed from Lent village, and thus on stories of grief and the citizen group's alternative plan. A success story for the local authority in the media is 'like rubbing salt in a wound,' the alderman stated.

However, he kept close contact with the journalist from the local newspaper, the most important news medium with regard to this project. 'I informed him upfront, told him about the considerations. Sometimes I gave him things, sometimes a scoop. I called him a lot, and was always available to him. He could even call me at eleven o'clock in the evening, if he wanted to. And I never ran away from him.' Nevertheless, this journalist always combined the alderman's story with that of the inhabitants, he argued. This was not always positive for the legitimising of the alderman's actions and decisions. The alderman in the IJsseldelta-Zuid case had a similar experience. He described media reports after press conferences as 'only one quarter of the page which covers our part of the story and three quarters of the page was filled with the citizen group's story.'

The political authorities had trouble proactively 'selling' their project to the public. According to the Kampen alderman, the political authorities 'were frequently 
pushed into a reactive position, instead of proactively communicating about the project. This almost killed our project, because it strongly influenced the public image.' The IJsseldelta-Zuid citizen group played an important role in this matter. According to them, the bypass would create more possible victims in the event of flooding than the scenario without a bypass. This made it very hard for the political authorities to communicate their plans. 'You find yourself in a reactive position, although it [citizen group's statement] was bullshit, because we can prove that it is incorrect. However, you have to react to their story, while the tone is already set. And if the media do not hear you at the same time, but the next day or something, your story comes second. Then, things become complicated.' This example shows how political authorities sometimes have to fight against a public image which, according to them, is highly incorrect. This public image can delegitimise their proposed decisions or plans. Recently, the authorities involved in the project consciously decided not to react anymore to all negative stories in the media. 'When we, the steering committee, gave less attention to these stories, we noticed that journalistic attention for them disappeared as well,' the alderman argued. Hence, ignoring negative stories in the media can also be a communication strategy.

In contrast, the alderman involved in the Noordwaard project noted that listening to and dealing with the emotions of citizens and showing that he understands them is a major part of his message to the press: 'always show the press that you can handle empathy and emotions well as a governor,' he declared. In that regard, he thought it important to openly make concessions on his plans for recreational facilities and mediate for the relevant inhabitants in the compensation negotiations. This is more comparable to the strategies of the alderman in Lent.

Nevertheless, what all aldermen have in common is a more reactive communication strategy, to which they sometimes feel condemned by the role of the media and media logic in the projects.

The findings in sections 3.1 and 3.2 are summarised in Table 4. 
Table 4. Influence of media logic on the sources of legitimacy

\begin{tabular}{|c|c|c|c|}
\hline & Role of media & Media logic & \\
\hline Voice & $\begin{array}{l}\text { The media are a vehicle to } \\
\text { generate attention for certain } \\
\text { issues and to gain influence }\end{array}$ & $\begin{array}{l}\text { Increases } \\
\text { possibilities }\end{array}$ & $\begin{array}{l}\text { The citizen groups succeed in attracting media } \\
\text { attention by adapting to media logic and are able to } \\
\text { put their issues on the political agenda. }\end{array}$ \\
\hline Due deliberation & $\begin{array}{l}\text { The media as watchdog, as a } \\
\text { check and balance in the } \\
\text { process, platform for diverse }\end{array}$ & $\begin{array}{l}\text { Increases } \\
\text { possibilities }\end{array}$ & $\begin{array}{l}\text { The deliberation process is broadened by the } \\
\text { perspectives of the citizen groups, partly because of } \\
\text { media attention. }\end{array}$ \\
\hline & deliberations & $\begin{array}{l}\text { Decreases } \\
\text { possibilities }\end{array}$ & $\begin{array}{l}\text { Since media are more interested in entertaining } \\
\text { stories, with a focus on conflicts and drama, this } \\
\text { partly reduces the quality of the deliberation } \\
\text { process. Images seem more important than well } \\
\text { elaborated deliberations. The media are a platform } \\
\text { more for the citizen groups than for the authorities. }\end{array}$ \\
\hline Accountability & $\begin{array}{l}\text { The media are a } \\
\text { communication channel for } \\
\text { generating transparency and } \\
\text { accountability }\end{array}$ & $\begin{array}{l}\text { Decreases } \\
\text { possibilities }\end{array}$ & $\begin{array}{l}\text { The media sometimes force political authorities into } \\
\text { a reactive communication style: they have to fight } \\
\text { against a negative image. Proactive communication, } \\
\text { such as branding, is difficult in the context of the } \\
\text { citizens' dramatic stories. }\end{array}$ \\
\hline
\end{tabular}

\section{Conclusion and Discussion}

Although theoretical and empirical work on the democratic legitimacy of governance networks is growing (e.g. Pierre 2000, Papadopoulos 2003, Sørensen and Torfing 2005, van Meerkerk et al. 2014), the role of the media and particularly media logic in this respect has so far been neglected. In this research, we aimed to start to fill this lacuna. Before we present our conclusions however, we want to mention several important research choices and limitations of our study. A first important choice was the local-level focus. Media communications by politicians may be characterised by a lower level of professionalisation than is described by the national-level focused literature on PR and news management (cf. Davis 2002, Cook 2005). Local-level politicians often have fewer resources regarding communication, but this may differ between organisations and projects. Furthermore, as we studied cases in the field of water management, our results cannot automatically be assumed to hold for other types of public projects or policy domains. The role of the media in less technical and more controversial public issues is likely to be stronger, especially because of media logic.

We can conclude that the media attention in the three cases was highly inconstant. This is in line with other research (Cobb and Elder 1983, Baumgartner and Jones 2009). 
Most media attention occurred in the decision rounds in which citizen groups strongly contested the policy plans. This points to the role and presence of media logic, with its focus on conflict and negativity, as was confirmed by the results of the content analysis.

Although in a lot of the literature the role of the media in legitimacy relations is stressed (e.g. Bang 2003, Habermas 2006, Louw 2007), the role of media logic in these relationships is not yet well examined. In this study, media logic extended the possibilities for citizen groups to voice their views. The citizen groups in our cases seem to know how the media work and are capable of adapting their stories to media logic. They often strategically strove for media attention, and they benefitted from media logic to challenge political authorities and influence the decision-making process. This is in line with Schudson's (2009) claim that the characteristics of media logic give journalists and citizens the possibility to subvert established power in a deliberative process. However, these mediatised voice possibilities for citizens are dependent on the capacity and will of citizens to adapt to media logic. This means that citizen groups need to provide some drama and conflicts, otherwise journalists will not be that interested (see also Cook 2005, Hajer 2009).

In the case studies, we observed that citizen groups deployed media strategies at times when they were losing faith in the interactive governance process (Noordwaard, Lent) or when they were fighting for their last chance to influence the decision-making process (IJsseldelta-South). Although these media strategies extend their influence possibilities, they are not without risks. They could influence trust relationships between the citizen groups and the other actors or even isolate them from the interactive governance process. There are also other challenges. To what extent is it legitimate to listen to these actors, barking loudly in the media, while other stakeholders are trying to reach compromises in an interactive setting? The aldermen in both the Lent and the IJsseldelta-Zuid case experienced this dilemma. Further research could be done to examine what kind of dilemmas actors within governance networks face in this respect and how they deal with them.

Furthermore, through the workings of media logic, the deliberation process broadened, but this did not improve the quality of this process per se, as negative and dramatised images seem to dominate over substantial argumentation. This connects with 
the literature that doubts the quality of media reporting, providing more drama and less information about the complexity of societal issues from different viewpoints (e.g. Patterson 2000, Bennett 2009). Extensive qualitative content analysis of media reports could lead to firmer claims in this regard.

A next conclusion is that local political authorities had great difficulty legitimising their actions. The literature suggests that authorities could proactively use the media to 'sell' their policies (Davis 2002, Cook 2005, Bennett 2009, Eshuis and Klijn 2012), but the political authorities did not really feel capable of doing this as they were pushed into a rather reactive position (cf. Hajer 2009).

In this study, we thus see a mediatisation of legitimacy sources at certain stages of the policy process, namely, those that contain conflict and drama, leading to some changes in the policy process and outcomes in favour of citizen groups who are able to attract media attention. At these stages, media logic might overrule the logic of deliberative governance processes to some extent.

\section{References}

Altheide, D.L. and Snow, R.P., 1979. Media logic. Beverly Hills, CA: Sage.

Bang, H. P., ed., 2003. Governance as social and political communication. Manchester: Manchester University Press.

Baumgartner, F.R. and Jones, B.D., 2009. Agendas and instability in American politics. $2^{\text {nd }}$ ed. Chicago: Chicago University Press.

Beck, U., Bonß, W., and Lau, C., 2003. The theory of reflexive modernization: problematic, hypothesis and research programme. Theory, Culture \& Society, 20 (2), 135 .

Bekkers, V. and Edwards, A., 2007. Legitimacy and democracy: a conceptual framework. In: V. Bekkers, G. Dijkstra, E. Edwards, and M. Fenger,eds. Governance and the democratic deficit. Hampshire: Ashgate, 35-60.

Bennett, W.L., 2009. News. The politics of illusion. $8^{\text {th }}$ ed. New York: Pearson, Longman.

Brants, K. and Neijens, P., 1998. The infotainment of politics. Political Communication, $15,149-164$.

Brants, K. and van Praag, P., 2006. Signs of media logic. Half a century of political communication in the Netherlands. Javnost - The Public, 13 (1), 25-40. 
Cobb, R.W. and Elder C.D., 1983. Participation in American politics. The dynamics of agenda-building. Baltimore, MD: The Johns Hopkins University Press.

Cohen, J., 1989. Deliberation and democratic legitimacy. In: A. Hamlin and P. Pettit, eds. The good polity: normative analysis of the state. Oxford: Basil Blackwell, 17-34.

Cook, F.L. et al., 1983. Media and agenda setting: effects on the public, interest group leaders, policy makers, and policy. Public Opinion Quarterly, 47(1), 16-35.

Cook, T., 2005. Governing with the news. Chicago: University of Chicago Press.

Crozier, M., 2008. Listening, learning, steering: new governance, communication and interactive policy formation. Policy \& Politics, 36 (1), 3-19.

Currall, S.C. and Towler, A.J., 2003. Research methods in management and organizational research: towards an integration of qualitative and quantitative techniques. In: A. Tashakkori, and C. Teddlie, eds. Handbook of mixed methods in social \& behavioral research. Thousand Oaks, CA: Sage, 513-526.

Davis, A. 2002. Public relations democracy. Public relations, politics and the mass media in Britain. Manchester: Manchester University Press.

Davis, A., 2007. The mediation of power: a critical introduction. London: Routledge.

Dryzek, J., 2000. Deliberative democracy and beyond. Oxford: Oxford University Press.

Dryzek, J., 2007. Networks and democratic ideals: equality, freedom, and communication. In: E. Sørensen and J. Torfing, eds. Theories of democratic network governance. London: Palgrave, 262-273.

Dryzek, J., 2010. Foundations and frontiers of deliberative governance. Oxford: Oxford University Press.

Edelenbos, J., Klijn, E.H. and Buuren, M.W. van, 2013. Connective capacities of network managers: A comparative study of management styles in eight regional governance networks. Public Management Review, 15(1), 131-160.

Edelenbos, J. and Teisman, G.R., 2011. Symposium on water governance. Prologue: water governance as a government's actions between the reality of fragmentation and the need for integration. International Review of Administrative Sciences, 77(1), 5-30.

Entman, R.M., 2007. Framing bias: media in the distribution of power. Journal of Communication, 157, 163-173. 
Eshuis, J. and Klijn, E.H., 2012. Branding in governance and public management. New York: Routledge.

Esser, F. and Matthes, J., 2013. Mediatization effect on political news, political actors, political decisions, and political audiences. In: H. Kriesi, S. Lavenex, F. Esser, J. Matthes, M. Bülmann and D. Bochsler, eds. Democracy in the age of globalization and mediatization. Hampshire: Palgrave Macmillan

Fischer, F., 2003. Reframing public policy; discursive politics and deliberative practices. Oxford: Oxford University Press.

Graber, D., 2003. The media and democracy: beyond stereotypes. Annual Review of Political Science, 6, 139-160.

Graber, D., 2004. Mediated politics and citizenship in the twenty-first century. Annual Review of Psychology, 55, 545-571.

Habermas, J., 2006. Political communication in media society: does democracy still enjoy an epistemic dimension? The impact of normative theory on empirical research. Communication Theory, 16, 411-426.

Hajer, M.A., 2003. Policy without polity? Policy analysis and the institutional void. Policy Sciences, 36, 175-195.

Hajer, M.A., 2009. Authoritative governance: policy-making in the age of mediatization. Oxford: Oxford University Press.

Held, D., 2006. Models of democracy. Cambridge: Polity Press.

Hjarvard, S., 2008. The mediatization of society: a theory of the media as agents of social and cultural change. Nordicom Review, 29 (2), 105-134.

Hurrelmann, A. et al., 2009. Why the democratic nation-state is still legitimate: a study of media discourses. European Journal of Political Research, 48, 483-515.

Jacobs, S., 2009. Aan de schandpaal of succesverhaal? Over verantwoording van een publieke organisatie aan media. [Pillorying an organization or success stories? About accountability of a public organization in the media] Master's thesis, University of Utrecht.

Kleinnijenhuis, J., van Hoof, A.M.J., and Oegema, D., 2006. Negative news and the sleeper effect of distrust. Harvard International Journal of Press and Politics, 11 (2), 86104. 
Klijn, E.H., 2011. Democratic legitimacy criteria in interactive governance and their empirical application. In: J. Torfing and P. Triantafillou, eds. Interactive policy-making, metagovernance and democracy. Essex: ECPR Press, 205-225.

Klijn, E.H., Steijn, B., and Edelenbos, J., 2010. The impact of network management on outcomes in governance networks. Public Administration, 88 (4), 1063-1082.

Korthagen, I. (2013). Who Gets on the News? The relation between media biases and different actors in news reporting on complex policy processes. Public Management Review, (ahead-of-print), 1-26.

Koppenjan, J. and Klijn, E.H., 2004. Managing uncertainties in networks. A network approach to problem solving and decision making. New York: Routledge.

Kunelius, R. and Reunanen, E., 2011. Media in political power: aParsonian view on differentiated mediatization of Finnish decision makers. The International Journal of Press/Politics, XX (X), 1-20.

Louw, E., 2007. The media and political process. London: Sage.

Luhmann, N., 1975. Legitimation durch verfaren [Procedural legitimation]. Darmstad: Luchterhand.

Manin, B., 1987. On legitimacy and political deliberation. Political Theory, 15 (3), 338368.

Mazzoleni, G. and Schulz, W., 1999. 'Mediatization' of politics: A challenge for democracy? Political Communication, 16 (3), 247-261.

McCombs, M.E., 2004. Setting the agenda: the mass media and public opinion. Cambridge: Polity Press.

van Meerkerk, I., Edelenbos, J., and Klijn, E.H., 2014. Connective management and governance network performance: the mediating role of throughput legitimacy. Findings from survey research on complex water projects in the Netherlands. Environment and Planning C: Government and Policy, advance online publication, doi:10.1068/c1345

Meyer, T., 2002. Media democracy: how the media colonize politics. Cambridge: Polity Press.

Papadopoulos, Y., 2003. Cooperative forms of governance: problems in democratic accountability in complex environments. European Journal of Political Research, 42, 473-501.

Parkinson, J., 2006. Rickety bridges: using the media in deliberative democracy. British Journal of Political Science, 36 (1), 175-183. 
Patterson, T.E., 2000. Doing well and doing good: how soft news and critical journalism are shrinking the news audience and weakening democracy - and what news outlets can do about it. Joan Shorenstein Center on the Press, Politics and Public Policy, Kennedy School of Government, Harvard University, Boston.

Peters, B.G., 2010. Bureaucracy and democracy. Public Organization Review, 10, 209222.

Pierre, J., ed., 2000. Debating governance: authority, democracy, and steering. Oxford: Oxford University Press.

Reunanen, E., Kunelis, R., and Noppari, E., 2010. Mediatization in context: consensus culture, media and decision making in the $21 \mathrm{st}$ century, the case of Finland. Communications, 35 (3), 287-307.

Rohlinger, D.A., 2007. American media and deliberative democratic processes. Sociological Theory, 25 (2), 122-148.

Schudson, M., 2009. Why democracies need an unlovable press. Cambridge: Polity Press.

Semetko, H.A. and Valkenburg, P.M., 2000 Framing European politics: a content analysis of press and television news. Journal of Communication, 50 (2), 93-109.

Shoemaker, P.J. and Reese, S.D., 1996. Mediating the message. Theories of influences on mass media content. New York: Longman.

Sørensen, E., 2002. Democratic theory and network governance. Administrative Theory and Praxis, 24 (4), 693-720.

Sørensen, E. and Torfing, J., 2005. The democratic anchorage of governance networks. Scandinavian Political Studies, 28, 195-218.

Spörer-Wagner, D. and Marcinkowski, F., 2010. Is talk always silver and silence golden? The mediatisation of political bargaining. Javnost - The Public, 17 (2), 5-26.

Strömbäck, J. and Esser, F., 2009. Shaping politics: mediatization and media interventionism. In: K. Lundby ed. Mediatization. Concept, changes, consequences. New York: Peter Lang, 205-224.

Strömbäck, J. and Shehata, A., 2007 Structural biases in British and Swedish election news coverage. Journalism Studies, 8 (5), 798-815.

Teisman, G.R., 2000. Models for research into decision-making processes: on phases, streams and decision-making rounds, Public Administration, 78 (4): 937-956. 
Terkildsen, N., Schnell, F.I., and Ling, C., 1998. Interest groups, the media, and policy debate formation: an analysis of message structure, rhetoric and source cues. Political Communication, 15, 45-61.

van Buuren, A.W., Edelenbos J. and Klijn, E.H., 2010. Gebiedsontwikkeling in woelig water. Over water governance bewegend tussen adaptief waterbeheer en ruimtelijke besluitvorming. [Area development in turbulent water. About water governance moving between adaptive water management and spatial planning]. Den Haag: Lemma.

van Kersbergen, K. and van Waarden, F., 2004. "Governance" as a bridge between disciplines. European Journal of Political Research, 43 (2), 143-171.

Wagenaar, H., 2007. Governance, Complexity, and Democratic Participation: How Citizens and Public Officials Harness the Complexities of Neighborhood Decline. American Review of Public Administration, 37(1), 17-50.

Warren, M.E., 2009. Governance-driven democratization. Critical Policy Studies, 3, 313.

\footnotetext{
${ }^{\mathrm{i}}$ As Sørensen $(2002,715)$ rightly points out: a governance network 'exhibits and aggravates inherent problems in some of the basic concepts of liberal democracy.' However, an extensive elaboration of the relationship between governance networks and traditional models of democracy is beyond the scope of this article. Interesting elaborations in this matter are, for example, provided by Sørensen (2002) and Dryzek (2007, 2010).

ii In Teisman's (2000) decision-making model, which relates especially to decision making and interactions between actors in governance networks, decision making is defined as an intertwined clew of a series of decisions taken by a variety of parties. The interactions between actors and the interdependence of actors are stressed. Rounds are distinguished by a crucial decision or event (e.g. the involvement of a new actor), defined by the researchers in retrospect, but based on the reconstruction of the process by the involved actors. The crucial decision or event is the beginning of a next round and generally serves as a focal point of reference for the actors involved.

iii IJsseldelta-Zuid, dijkteruglegging Lent and Noordwaard.

iv These categories can be found in Table 1 . They are recoded as dummy variables. We used the dummy variables of 'citizens group as key subject in news report' and 'executive politicians as key subject in news report' in our further analysis.

v In Dutch: werkgroep Zwartendijk (IJsseldelta-Zuid); Lentse Federatie (Lent); bewonersvereniging Bandijk (Noordwaard)

${ }^{v i}$ The interview with the Werkendam alderman (Noordwaard case) is an exception in this matter. This interview was by telephone and took about 45 minutes.

vii However, we must remark that regional television programmes are quite recent phenomena on the Internet. The earliest regional television item is from March 2006, and the date regional broadcasters started their broadcasting on the Internet may even differ per outlet. This may lead to small biases in the analysis.

${ }^{\text {viii }}$ Furthermore, the particular history of the small village Lent, 'annexed' by the city of Nijmegen ('David versus Goliath' as the interviewees called it) in 1998, provided an interesting narrative for the media to mention.
} 